\title{
The Effect of Vigor, Dedication and Absorption on the Employee Performance of PT Garuda Indonesia Cargo
}

\author{
Lalu Heri Saputra Jaya and Eny Ariyanto
}

\section{ABSTRACT}

This study aims to analyze the effect of vigor, dedication and absorption on the employee performance of PT Garuda Indonesia Cargo. The object of this study is the employees of PT Garuda Indonesia at the Head Office Cargo Directorate, which is located in the Cargo Area of Soekarno-Hatta Airport. The population of this study is 93 employees of PT Garuda Indonesia at the Head Office Cargo Directorate. The sampling method used is a census sample. Therefore, the sample of this study is 93 employees. Multiple linear regression analysis is used in this study with the help of the SPSS application version 26. The results of this study indicate that simultaneously, vigor, dedication and absorption have a positive and significant effect on employee performance. Partially, both vigor and dedication have a significant positive effect on employee performance. Meanwhile, absorption has no effect and is not significant. The magnitude of the influence ( $R$ Square) of vigor, dedication and absorption on employee performance is $48,1 \%$.

Keywords: Absorption, Dedication, Employee Performance, Vigor.

\author{
Submitted : July 29, 2021 \\ Published : August 21, 2021 \\ ISSN: 2507-1076 \\ DOI: $10.24018 /$ ejbmr.2021.6.4.1006 \\ Lalu Heri Saputra Jaya * \\ Master of Management, University of Mercu \\ Buana, Jakarta, Indonesia. \\ (e-mail: laluherisaputrajaya93@gmail.com) \\ Eny Ariyanto \\ Faculty of Economic and Business, \\ University of Mercu Buana, Jakarta, \\ Indonesia. \\ (e-mail: eny_ariyanto@yahoo.com)
}

*Corresponding Author

\section{INTRODUCTION}

The existence of the cargo industry in a country is very much needed as one of the important pillars of supporting the economy, because economic development requires adequate transportation and transportation services as a means of supporting in maximizing services. The development of the cargo industry today requires companies to continue to improve the best service by taking into account the factors that support the success of the organization. Human resources are the most important factor in an organization, in addition to capital factors, natural resources and other supporting factors. Likewise for PT Garuda Indonesia Cargo in its operations, certainly it cannot be separated from the role of its human resources (HR), by placing competent human resources and having a good work ethic as a vital factor in maintaining achievements. The achievement of company goals is strongly influenced by the individual performance of the employees in it. Realizing this, the management of PT Garuda Indonesia always implements HR management programs that are oriented to 3 main strategic focuses, namely: global talent management, integrated HR development, as well as optimizing performance, productivity and rewards [1].

One of the factors that influence employee performance is when employees feel engaged with their work which makes them excited, proud, and completely immerse themselves in their work both physically and emotionally. A high level of employee engagement is one of the factors that support organizational success [2]. Therefore, it is important for companies to understand the concept of work engagement, its meaning and implications for employers [3]. Engagement is a situation in which a person is emotionally and intellectually committed to the organization [4] which is characterized by vigor, dedication and absorption [5].

The results of the preliminary study stated that the performance of PT Garuda Indonesia Cargo was quite good from year to year. The number of cargoes from 2015 to 2018 significantly increased. However, in 2019 it decreased by $26,01 \%$ compared to 2018, cargo tonnage revenue in 2019 was 335.76 , reaching $70,94 \%$ of the predetermined target of 473.31 [1].

A preliminary survey of 29 employees showed that employees have not been able to fully carry out their duties properly, there are employees who are less able to cope with the main job well when there is a sudden change in work, employees still need new skills to adapt to changes in the assigned tasks, employees have not fully able to come up with ideas when completing their work, the enthusiasm of employees in carrying out daily tasks is still not optimal, the level of dedication of employees is not optimal, and also the level of concentration and accuracy of employees that need to be improved.

Previous researchers found mixed results between vigor, dedication, absorption, and performance. There are results which state that vigor on performance has a very weak significant positive effect [6], a weakly significant positive [7], [8] and a moderately significant positive [9], [10]. Dedication on performance has a weakly significant positive effect [10], a moderately significant positive [7]-[9], [11], and a significant positive [6], [12]. Meanwhile, absorption on performance has a very weak positive significant effect [6], [13], a weak positive significant [10], a moderate positive significant [7], [8], [11], and a significant positive [9].

Based on the explanations mentioned above regarding 
phenomena and research gaps, researchers are interested in studying more deeply about the effect of vigor, dedication, and absorption on employee performance.

\section{LITERATURE REVIEW}

\section{A. Employee Performance}

Performance can be interpreted as a comparison of the work of an employee with the work achievement standards that have been determined by the company [14]. It can be said that performance is the behavior of a person or organization that can be measured and assessed by policies that have been previously established or mutually agreed upon. With the support of the organization and objective policies, performance can produce maximum results and according to the expectations set in the form of goals or objectives both quantitatively and qualitatively.

Employee performance can be measured using 4 theoretical dimensions [15], namely; task performance which is defined as the main task assigned to employees, contextual performance which is employee behavior that supports the organizational, social and psychological environment in which central tasks are carried out, adaptive performance, namely employee skills in adapting to changes in work systems or work roles and counterproductive work behavior which is defined as counterproductive work behavior that is considered harmful to the welfare of the organization.

\section{B. Effect of Vigor on Employee Performance}

Vigor is a series of interrelated affective states experienced by employees where they work, referring to an employee's feelings related to physical strength, emotional energy and cognitive activity [16]. Vigor is one aspect of employee engagement which implies high employee energy at work and mental resilience and investment in actual work, along with a high level of persistence even when facing difficulties [17].

Vigor can be measured using the Utrecht Work Engagement Scale (UWES) which includes; high energy level of employees, high mental resilience at work, willingness to invest effort in work, persistence of employees even when facing difficulties [5].

Good performance results require a person's level of awareness to carry out duties and responsibilities. Characteristics of vigor in the form of energy levels and mental resilience at work are it shows effort and perseverance even in difficulties [18], it can spur employee performance to be more optimal and it is based on organizational expectations. Someone will tend to do useful things for the organization on their own awareness and will be driven towards positive tendencies behavior [16]. It can be concluded that vigor has a positive influence on employee performance.

This logic is supported by research results which state that vigor has a significant positive effect on employee productivity [6], performance [8], contextual and task performance [11].

\section{The Effect of Dedication on Employee Performance}

Dedication is defined as a person's emotionally stable and positive attitude towards work with the aim of achieving personally significant results (professional demands and identity) [19]. Meanwhile, according to [20], Job Dedication refers to a person's disciplined behavior at work which includes compliance in following the rules, working hard, having resilience in carrying out tasks and being able to take the initiative in solving problems.

Dedication can be measured using the Utrecht Work Engagement Scale (UWES) which includes: highly involved in work, feeling important and meaningful, enthusiastic, inspiring, proud and like the challenges [5].

The achievement of organizational goals and interests is strongly influenced by the performance and motivation of employees in carrying out their duties and responsibilities. Employee motivation to perform well is based on job dedication which can encourage employees to act intentionally in promoting the interests of the organization [20]. On the other hand, dedicated employees better understand and support the company's values and tend to go the extra mile in protecting the company's image. Thus, dedicated employees are assets for the company in achieving the set targets [12]. It can be concluded that dedication has a positive effect on employee performance.

This is in accordance with the results of research which states that dedication has a significant positive effect on productivity [6], growth, resilience, performance [12], contextual and task performance [11].

\section{Effect of Absorption on Employee Performance}

Absorption is one of the characteristics of employee engagement which refers to a person's state of mind that is more pervasive and persistent [5]. Engagement is a situation where a person has an emotional and intellectual commitment to the organization [4]. Absorption is the level of someone feeling who is focused on work so that he escapes from the surrounding environment. It has high concentration and is not aware of the time spent on a job [21].

Based on the Utrecht Work Engagement Scale (UWES) measurement model, absorption is measured by; full concentration at work, feeling happy and engrossed in work so that time seems to pass quickly, and it is difficult to get away from work [5].

A high level of absorption will result in better performance, because absorption represents an attitude of concentration and seriousness in work. This gives birth to a cautious attitude of employees who encourage them to be more thorough in their work, which in turn can improve the quality of work results. Absorption can help organizations achieve predetermined goals and targets, because employees who are absorbed in their work will be encouraged to fulfill their obligations at work [21]. It can be concluded that absorption has a positive effect on employee performance.

This logic is supported by research results which say that there is a moderately significant positive relationship between absorption and performance [8], contextual and task performance [11].

\section{E. Conceptual Framework and Hypotheses}

Referring to the theory and structure of the relationship between each variable as described above, this research has the following framework: 


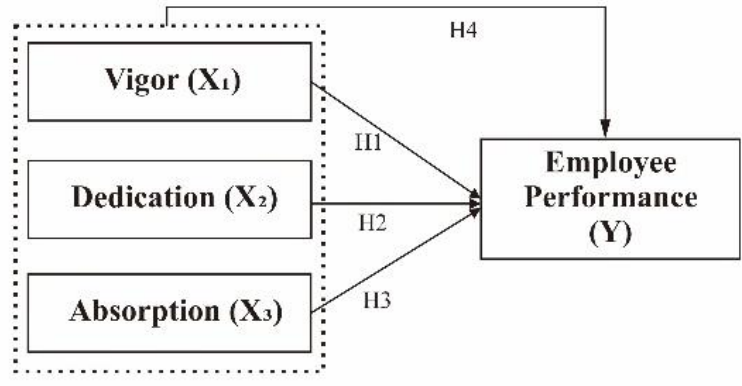

Fig. 1. Conceptual Framework.

The research hypothesis is formulated as follows:

H1: Vigor has a positive and significant effect on the Employee Performance of PT Garuda Indonesia Cargo.

H2: Dedication has a positive and significant effect on employee performance at PT Garuda Indonesia Cargo.

H3: Absorption has a positive and significant effect on employee performance at PT Garuda Indonesia Cargo.

H4: Vigor, Dedication and Absorption simultaneously have a positive and significant effect on the Employee Performance of PT Garuda Indonesia Cargo.

\section{RESEARCH METHOD}

This research is a quantitative research with a causal relationship approach. The independent variables consist of vigor, dedication, and absorption. While the dependent variable is employee performance. The variable measurement model uses a Likert scale. The population consists of all employees in the scope of PT Garuda Indonesia Cargo head office, which has 93 employees. The sampling technique used is a census sample, thus all members of the population are taken as sample. Primary data collection used is questionnaires. Data processing used is the Statistical Product and Service Solution (SPSS) application version 26.

\section{RESULTS AND DISCUSSION}

\section{A. Characteristics of Respondents}

Based on the results of data collection through questionnaires to 93 people, it is known that the characteristics of the majority of respondents are male $(69,9 \%)$, aged 20 - 30 years $(46,2 \%)$, have a Diploma level of education $(48,4 \%)$ and working period of $1-5$ years $(48,4 \%)$. This shows that most of the respondents are able to understand the current condition of the company.

\section{B. Validity and Reliability Test}

The result of validity and reliability test are obtained:

TABLE I: VALIDITY AND RELIABILITY TEST RESULTS

\begin{tabular}{cccc}
\hline Variable & r-count & r-table & Cronbach's Alpha \\
\hline Vigor & $0,373 \sim 0,778$ & 0,207 & 0,796 \\
Dedication & $0,221 \sim 0,777$ & 0,207 & 0,791 \\
Absorption & $0,541 \sim 0,828$ & 0,207 & 0,876 \\
Performance & $0,223 \sim 0,708$ & 0,207 & 0,897 \\
\hline
\end{tabular}

The results of the research instrument validity test show that the lowest r-count value for the vigor variable is 0,373 , the dedication variable is 0,221 , the absorption variable is 0,541 and the employee performance variable is 0,223 . When compared to the r-table value $(0,207)$, there is not a single statement item in the research instrument that is ruled out. It can be concluded that all statement items are valid.

Based on the results of the reliability test, it is known that the value of Cronbach's alpha of all instruments is greater than 0,60 , the vigor variable $=0,796$, dedication $=0,791$, absorption $=0,876$ and employee performance $=0,897$. Thus, all instruments are declared reliable.

\section{Classic Assumption Test}

Normality test is carried out through the normal P-P Plot test by looking at the spread of points on the diagonal axis of the graph.

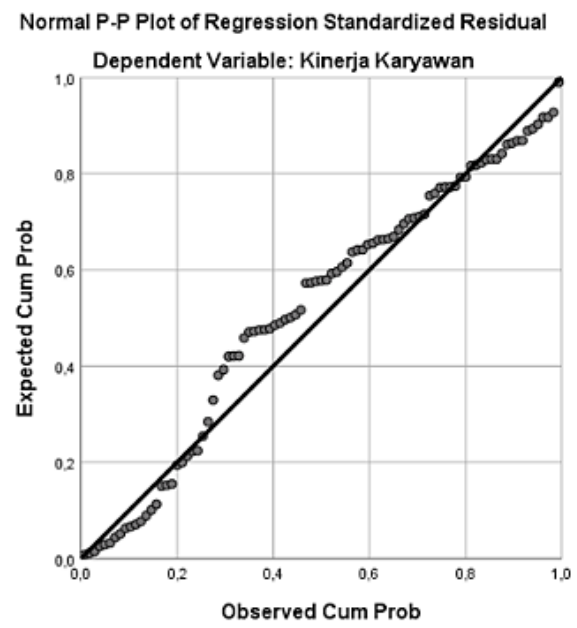

Fig. 2. Normality test result.

The results of the instrument test show that the data or points spread around the diagonal line and follow the direction of the diagonal line, this indicates that the regression model meets the assumption of normality.

Multicollinearity test results show that the tolerance value for each variable is vigor $=0,726$, dedication $=0,715$ and absorption $=0,630$. While the value of Variance Inflation Factor $(\mathrm{VIF})$ for each variable is vigor $=1,378$, dedication $=$ 1,398 and absorption $=1,588$. In this case, it can be interpreted that all variables have a tolerance value greater than 0,1 and a VIF value less than 10. It can be concluded that there are no symptoms of multicollinearity.

Heteroscedasticity test is done using Spearman rho, the test results show that all independent variables have a significance value $(>0,05)$. The value of sig. (2-tailed) for vigor $=0,793$ dedication $=0,806$ and absorption $=0,617$. Thus, it can be concluded that there is no symptom of heteroscedasticity.

\section{Multiple Linear Regression Analysis}

The results of the multiple linear regression of vigor, dedication, absorption, and employee performance are as follows:

Based on the table below, the multiple linear regression equation model can be formulated as follows:

$$
\mathrm{Y}=1,329+0,252\left(\mathrm{X}_{1}\right)+0,418\left(\mathrm{X}_{2}\right)+0,015\left(\mathrm{X}_{3}\right)
$$

This means that vigor, dedication, and absorption have a positive influence on performance. 
TABLE II: MULTIPLE LINEAR REGRESSION RESULTS Coefficients $^{\text {a }}$

\begin{tabular}{|c|c|c|c|c|c|c|}
\hline & \multirow[t]{2}{*}{ Model } & \multicolumn{2}{|c|}{$\begin{array}{c}\text { Unstandardized } \\
\text { Coefficients }\end{array}$} & \multirow{2}{*}{$\frac{\begin{array}{c}\text { Standardized } \\
\text { Coefficients }\end{array}}{\text { Beta }}$} & \multirow[t]{2}{*}{$\mathrm{t}$} & \multirow[t]{2}{*}{ Sig. } \\
\hline & & B & Std. Error & & & \\
\hline \multirow{4}{*}{1} & (Constant) & 1,329 & 0,341 & & 3,893 & 0,000 \\
\hline & Vigor & 0,252 & 0,083 & 0,272 & 3,035 & 0,003 \\
\hline & Dedication & 0,418 & 0,072 & 0,524 & 5,801 & 0,000 \\
\hline & Absorption & 0,015 & 0,056 & 0,026 & 0,271 & 0,787 \\
\hline
\end{tabular}

a. Dependent Variable: Employee performance.

Partial effect testing is done by assessing the t-count value for each variable, it is known that for the vigor variable the $t$ count value $=3,035$ with t-table $=1,991$ and significance $=$ 0,003 , it can be interpreted that the vigor partially has an effect and is significant on performance employee. Thus, hypothesis 1 is accepted.

The t-count value for the dedication variable $=5,801$ with $\mathrm{t}$-table $=1,991$ and significance $=0,000$. It can be concluded that partially, dedication has an effect and is significant on employee performance. Thus hypothesis 2 is accepted.

The $\mathrm{t}$-count value for absorption variable $=0,271$ with $\mathrm{t}$ table $=1,991$ and significance $=0,787$, it can be concluded that absorption has no effect and no significant effect on employee performance. Thus, hypothesis 3 is rejected.

The following table is the result of the F-statistics test:

TABLE III: F-STATISTICS

\begin{tabular}{|c|c|c|c|c|c|c|}
\hline \multicolumn{7}{|c|}{ ANOVA $^{a}$} \\
\hline & Model & $\begin{array}{l}\text { Sum of } \\
\text { Squares }\end{array}$ & df & $\begin{array}{l}\text { Mean } \\
\text { Square }\end{array}$ & $\mathrm{F}$ & Sig. \\
\hline \multirow{3}{*}{1} & Regression & 5,340 & 3 & 1,780 & 27,465 & $0,000^{\mathrm{b}}$ \\
\hline & Residual & 5,767 & 89 & 0,065 & & \\
\hline & Total & 11,107 & 92 & & & \\
\hline
\end{tabular}

a. Dependent Variable: Employee performance.

b. Predictors: (Constant), Absorption, Vigor, Dedication.

Simultaneous effect testing is done by comparing the Fcount value with the F-table and the significance. Based on the table above, it is known that the F-count $=27,465$ with the F-table $=2,76$ and the significance value $=0,000$. It can be concluded that simultaneously, vigor, dedication and absorption have a positive and significant effect on employee performance. Thus hypothesis 4 is accepted.

\section{E. Coefficient of Determination Test}

The result of coefficient of determination are obtained:

TABLE IV: COEFFICIENT OF DETERMINATION

\begin{tabular}{ccccc}
\hline \multicolumn{5}{c}{ Model Summary } \\
\hline Model & R & R Square & $\begin{array}{c}\text { Adjusted R } \\
\text { Square }\end{array}$ & $\begin{array}{c}\text { Std. Error of } \\
\text { the Estimate }\end{array}$ \\
\hline 1 & $0,693^{\text {a }}$ & 0,481 & 0,463 & 0,25456397 \\
\hline a. Predictors: (Constant), Absorption, Vigor, Dedication
\end{tabular}

From the table above, it is known that the value of $\mathrm{R}$ Square (R2) is 0,481 . This shows that the magnitude of the effect of vigor, dedication and absorption on employee performance is $48,1 \%$. While the value of $\mathrm{R}=0,693$ which means that there is a strong relationship between vigor, dedication, and absorption with employee performance.

\section{DISCUSSION}

Vigor has a positive and significant effect on the employee performance of PT Garuda Indonesia Cargo. Vigor has an influence on the high and low performance of employees. High employee work vigor can improve employee performance, and vice versa. In accordance with the results of the research by [6], [8], [9], [11], [13].

The results of observations show that the level of employee vigor is at a good level, this can be seen from the high energy level of employees in carrying out their main tasks and functions, the enthusiasm they have to get the expected work results, high mental strength when they work, their willingness and willingness to put effort into their work and perseverance in both normal and difficult circumstances. The spirit of employees at work can improve employee performance and organizational effectiveness, this is because vigor is closely related to employee motivation at work [16].

Persistence has a very strong relationship to employee task performance. This shows that so far, the management of PT Garuda Indonesia Cargo has placed more emphasis on employee persistence in improving their performance. This is necessary because the competition in the freight service sector today really requires accuracy and speed of service. However, high energy levels and morale have a weak relationship. The company still pays less attention to the energy and enthusiasm of employees in working to improve the quality of their task performance.

Dedication has a positive and significant effect on the employee performance of PT Garuda Indonesia Cargo. This means that dedication has an effect on the level of employee performance, the higher the level of employee dedication, the higher the employee's performance as well. On the other hand, low employee dedication to work can lead to low employee performance. In line with the results of the research by [12] which stated that dedication had a significant positive effect on performance, productivity, growth and resilience. [8] also stated that there was a significant positive relationship between dedication and performance. The level of dedication of employees of PT Garuda Indonesia Cargo is at a good level as indicated by the majority of employees feeling that they have meaning and purpose in their work, have an enthusiastic attitude, take work as inspiration, feel proud of their work and feel challenged. Companies need dedicated employees who can encourage them to act intentionally in promoting the interests of the organization [20] and achieve the set targets [12].

Enthusiasm and feeling of having meaning and purpose in work are significantly related to the ability to adapt to the work environment. It can be said that the company has been emphasizing the enthusiasm of employees and making them feel that their existence is indispensable in the company, which in the end can encourage their motivation to always maintain their knowledge and skills properly. However, efforts to make them feel challenged and proud of their work need more attention from the management of PT Garuda Indonesia.

Absorption has no effect and is not significant on the performance of PT Garuda Indonesia Cargo employees. A high level of employee absorption does not make employee performance increase, and vice versa, low absorption does not make employee performance decrease. This is different from 
the research results which state that absorption has a significant positive effect on employee productivity [6] and job performance [11]. Absorption is the feeling of a person breaking away from the surrounding environment, high concentration and not paying attention to the time that passes [21].

Observation results show that most employees enjoy work and feel happy and engrossed when working. Feelings of pleasure and fun at work have a moderate relationship with adaptive performance. On the other hand, working accurately has a very weak relationship with counterproductive work behavior.

Vigor, dedication, and absorption (simultaneous) have a significant positive effect on employee performance with a magnitude of $48,1 \%$. The higher the level of employee engagement (vigor, dedication, and absorption) will lead to higher employee performance. Low levels of employee engagement (vigor, dedication, and absorption) can cause performance to decline. In line with the results of research which stated that engagement (vigor, dedication and absorption) has a positive and significant effect on employee performance [22], [23] and task performance [24], [25].

\section{CONCLUSION}

Based on the results of the research conducted, the researchers conclude that:

1) Vigor has a positive and significant effect on the employee performance of PT Garuda Indonesia Cargo.

2) Dedication has a positive and significant effect on the employee performance of PT Garuda Indonesia Cargo.

3) Absorption has no effect and is not significant on the employee performance of PT Garuda Indonesia Cargo.

4) Vigor, dedication and absorption simultaneously have a positive and significant effect on employee performance.

\section{SUGGESTION}

Referring to the results of the study, the suggestions to improve the employee performance of PT Garuda Indonesia Cargo is as follows:

1) The company needs to maintain employee persistence by making policies that are able to make employees even more active in carrying out their main tasks and functions, such as providing compensation and bonuses for excel employees. This will help the company in accelerating employee performance in achieving the predetermined targets.

2) The company needs to further improve the mental strength of its employees in dealing with various situations that may occur when there is a change in tasks or roles by providing the necessary training and development.

3) The company needs to pay more attention to the enthusiasm and energy of employees shown when working by adjusting the tasks given. For this reason, the company can apply the SMART concept (specific, measurable, achievable, reasonable, time bound).

4) The company needs to maintain the level of enthusiasm and inspiration of employees by motivating them that their existence is very valuable for the company, so that they feel they have meaning and purpose.

5) The company provides challenging tasks by implementing an assessment system for work performance, offering a variety of tasks, and providing opportunities to maximize skills.

6) The company creates a conducive working environment that can encourage employees to be more focused on completing work targets.

7) The company develop a sense of employee engagement in the company by providing good leadership qualities, maintaining good relations between employees, providing welfare for employees, and making objective policies that can influence the extent to which employees are involved.

8) For further research, it is hoped that other variables can be used which positively influence employee performance, such as leadership style, motivation, competence, organizational citizenship behaviour and others.

\section{REFERENCES}

[1] G. Indonesia, "Standing Strong into the Future (Annual Report Garuda Indonesia 2019)," 2019. [Online]. Available: https://www.garudaindonesia.com/content/dam/garuda/files/pdf/investorrelations/report/AR2019.pdf.

[2] K. S. Kumar, R. Arasu, and S. Nagarajan, "The Impact of Employee Engagement on Employee Empowerment," Harv. Bus. Rev., no. May, pp. 1-8, 2014, [Online]. Available: hbr.org/hbr-analytic-services.

[3] B. Motyka, "Employee engagement and performance: a systematic literature review," Int. J. Manag. Econ., vol. 54, no. 3, pp. 227-244, 2018, doi: 10.2478/ijme-2018-0018.

[4] S. Riyanto, E. Ariyanto, and L. Lukertina, "Work Life Balance and Its Influence on Employee Engagement ' $Y$ ' Generation in Courier Service Industry," Int. Rev. Manag. Mark., vol. 9, no. 6, pp. 25-31, 2019, doi: 10.32479/irmm.8499.

[5] W. B. Schaufeli, "Work Engagement. What Do We Know and Where Do We Go? Work Engagement in Everyday Life, Business, and Academia," Rom. J. Appl. Psychol., vol. 14, no. 1, pp. 3-10, 2012.

[6] J. Hanaysha, "Improving employee productivity through work engagement: Evidence from higher education sector," Manag. Sci. Lett., no. January, pp. 61-70, 2016, doi: 10.5267/j.msl.2015.11.006.

[7] R. J. Burke and G. El-Kot, "Work engagement among managers and professionals in Egypt: Potential antecedents and consequences," African J. Econ. Manag. Stud., vol. 1, no. 1, pp. 42-60, 2010, doi: 10.1108/20400701011028158.

[8] A. A. Shusha and A. Abdelkader, "Work engagement in higher education in Egypt: The influence on academic work performance," Int. J. Bus. Perform. Manag., vol. 17, no. 2, pp. 132-146, 2016, doi: 10.1504/IJBPM.2016.075535.

[9] K. Sendawula, S. Nakyejwe Kimuli, J. Bananuka, and G. Najjemba Muganga, "Training, employee engagement and employee performance: Evidence from Uganda's health sector," Cogent Bus. Manag., vol. 5, no. 1, pp. 1-12, 2018, doi: 10.1080/23311975.2018.1470891.

[10] K. Sittar, "Relationship of Work Engagements and Job Performance of University Teachers.," Bull. Educ. Res., vol. 42, no. 1, pp. 167-183, 2020.

[11] H. Fan and D. Cai, "Employee Engagement and Job Performance of Employees - a Study from Hospitality and Tourism in Hainan," DEStech Trans. Soc. Sci. Educ. Hum. Sci., no. eemt, pp. 586-591, 2017, doi: 10.12783/dtssehs/eemt2017/14542.

[12] M. R. Bamidele and K. T. Konya, "Employee Dedication and Performance of Transport Operators in the Marine Sector in," vol. 5, no. 5, pp. 18-33, 2019.

[13] M. Al-dalahmeh, R. Masa'deh, R. K. Abu Khalaf, and B. Y. Obeidat, "The Effect of Employee Engagement on Organizational Performance Via the Mediating Role of Job Satisfaction: The Case of IT Employees in Jordanian Banking Sector," Mod. Appl. Sci., vol. 12, no. 6, p. 17, 2018, doi: 10.5539/mas.v12n6p17.

[14] A. Permana, M. H. Aima, E. Ariyanto, and A. Nurmahdi, "The effect of leadership style, motivation and discipline of employee performance with understanding of islamic work ethics," Int. J. Sci. Technol. Res., vol. 8, no. 8, pp. 1098-1106, 2019. 
[15] L. Koopmans, C. Bernaards, V. Hildebrandt, S. Van Buuren, A. J. Van Der Beek, and H. C. w. de Vet, "Development of an individual work performance questionnaire," Int. J. Product. Perform. Manag., vol. 62, no. 1 , pp. 6-28, 2012, doi: 10.1108/17410401311285273.

[16] Arie Shirom, "Feeling energetic at work: On vigor's antecedents," in Work engagement: A handbook of essential theory and research. ProQuest Ebook Central https://www.proquest.com, 2010, pp. 69-84.

[17] H. Shekari, "Evaluating the Three Dimensions of Work Engagement in Social Security Organization of Yazd Province in Iran," J. Educ. Manag. Stud., vol. 5, no. 3, pp. 168-174, 2015, [Online]. Available: www.science-line.com

[18] A. B. Bakker, W. B. Schaufeli, M. P. Leiter, and T. W. Taris, "Work engagement: An emerging concept in occupational health psychology," Work Stress, vol. 22, no. 3, pp. 187-200, 2008, doi: $10.1080 / 02678370802393649$.

[19] V. V. Sadovaya and G. I. Korchagina, "Psychological model of a person dedicated to his profession," Int. J. Environ. Sci. Educ., vol. 11, no. 8, pp. 2047-2057, 2016, doi: 10.12973/ijese.2016.577a.

[20] J. R. Van Scotter and S. J. Motowidlo, "Interpersonal facilitation and job dedication as separate facets of contextual performance," J. Appl. Psychol., vol. 81, no. 5, pp. 525-531, 1996, doi: 10.1037/00219010.81.5.525.

[21] B. A. Rayton and Z. Y. Yalabik, "Work engagement, psychological contract breach and job satisfaction," International Journal of Human Resource Management, vol. 25, no. 17. Taylor \& Francis, pp. 23822400, 2014, doi: 10.1080/09585192.2013.876440.

[22] A. J., "Determinants of employee engagement and their impact on employee performance," Int. J. Product. Perform. Manag., vol. 63, no. 3, pp. 308-323, 2014, doi: 10.1108/IJPPM-01-2013-0008.

[23] J. van Wingerden, D. Derks, and A. B. Bakker, "Facilitating interns' performance: The role of job resources, basic need satisfaction and work engagement," Career Dev. Int., vol. 23, no. 4, pp. 382-396, 2018 , doi: 10.1108/CDI-12-2017-0237.

[24] G. Yongxing, D. Hongfei, X. Baoguo, and M. Lei, "Work engagement and job performance: The moderating role of perceived organizational support," An. Psicol., vol. 33, no. 3, pp. 708-713, 2017, doi: 10.6018/analesps.33.3.238571.

[25] N. Yin, "The Effect of Job Engagement on Job Burnout and Job Performance: The Moderating Effect of Organizational Justice," Int. J. Bus. Manag., vol. 12, no. 5, p. 177, 2017, doi: 10.5539/ijbm.v12n5p177. 